\title{
Nitrite Toxicity to Danio Rerio: Effects of Fish Age and Chloride Concentrations
}

\author{
E. VOSLÁŘOVÁ, V. PIŠTĚKOVÁ, Z. SVOBODOVÁ \\ Department of Public Veterinary Medicine and Toxicology \\ University of Veterinary and Pharmaceutical Sciences Brno, Czech Republic \\ Received October 17, 2005 \\ Accepted March 16, 2006
}

\begin{abstract}
Voslářová E., V. Pištěková, Z. Svobodová: Nitrite Toxicity to Danio Rerio: Effects of Fish Age and Chloride Concentrations. Acta Vet. Brno 2006, 75: 107-113.

The aim of the present study was to compare the acute nitrite toxicity for Danio rerio at the age of 20 - 25 days (larval stage) and $2-3$ months (juvenile stage) at various chloride concentrations. The semistatic method according to OECD 203 was used in the tests. The $96 \mathrm{hLC} 50 \mathrm{NO}_{2}{ }^{-}$value was $386.00 \pm 29.75 \mathrm{mg} \cdot \mathrm{l}^{-1}$ (D. rerio aged $20-25$ days), and $242.41 \pm 13.67 \mathrm{mg} \cdot \mathrm{l}^{-1}$ (D. rerio aged $2-3$ months), respectively, at $19 \mathrm{mg} \mathrm{Cl}^{-} \cdot \mathrm{l}^{-1}$ in diluting water. We observed an increase in $96 \mathrm{hLC} 50$ $\mathrm{NO}_{2}{ }^{-}$in $D$. rerio of both developmental stages following an increase in $\mathrm{Cl}^{-}$concentration in diluting water. A comparison between the $96 \mathrm{hLC} 50 \mathrm{NO}_{2}{ }^{-}$determined for D. rerio aged $20-25$ days and those aged $2-3$ months at different chloride concentrations in diluting water $\left(19 ; 50 ; 100 \mathrm{mg} \cdot \mathrm{l}^{-1}\right)$ showed a highly significant increase $(p<0.01)$ in the $96 \mathrm{hLC} 50 \mathrm{NO}_{2}-$ for the younger fish at all chloride concentrations. An exponential relationship between $96 \mathrm{hLC}^{2} 0 \mathrm{NO}_{2}{ }^{-}$values and chloride concentrations in diluting water $(\mathrm{I}=0.849)$ was demonstrated in $D$. rerio aged $20-25$ days while a logarithmical relationship $(\mathrm{I}=0.856)$ was observed in $D$. rerio aged $2-3$ months.
\end{abstract}

Cyprinus rerio, zebrafish, 96hLC50, $\mathrm{NO}_{2}$, competition $\mathrm{NO}_{2}$ and $\mathrm{Cl}^{-}$, fish size

Nitrite $\left(\mathrm{NO}_{2}^{-}\right)$is a naturally occurring anion in fresh and saline waters, its concentration in oxygenated waters is typically less than $0.005 \mathrm{mg} \cdot \mathrm{l}^{-1}$ (Lewis and Morris 1986). Elevated concentration of nitrite can be found in water receiving nitrogenous effluents, in various hypoxic environments or in effluents from industries producing metal, dyes, and celluloid (Pitter 1999). The increased nitrite concentrations in water also present one of the frequent problems encountered both in aquaria and on fish farms. Sources of nitrites are mainly products of fish metabolism and decaying remains of food and faeces. In aquaria, fish are most frequently poisoned by nitrites that accumulate in the tank as a result of insufficient efficiency of biological filters (Adamsson et al. 1998; Etscheidt 2003; Dvořák 2004; Svobodová et al. 2005a). An elevated ambient nitrite concentration is a potential problem for freshwater fish, since nitrite is actively taken up across the gills in competition with chloride (Maetz 1971; Williams and Eddy 1986; Jensen 2003).

Nitrite toxicity to fish varies considerably and depends on a large number of external and internal factors whose importance is continuously verified and re-assessed. One of the important factors influencing nitrite toxicity for fish is the fish size and age. Lewis and Morris (1986) stated that small fish, even larvae, are unlikely to be more sensitive to nitrite than larger fish of the same species, and that there is definite evidence for some species that very small fish are less vulnerable to toxicity than fish of intermediate or large size. A study by Perrone and Meade (1977) indicated that coho salmon (Oncorhynchus kisutch) fry have greater tolerance to nitrite than coho yearlings. This phenomenon has been also observed in other species of salmonids. An early study by S mith and Williams (1974) on rainbow trout (Salmo gairdneri) showed that small fish were less sensitive to $24 \mathrm{~h}$ exposures of nitrite than larger ones. Russo et al. (1974) showed that rainbow trout larvae were slightly less susceptible to nitrite than larger fish and subsequent studies by Russo and

Address for correspondence:

Ing. Eva Voslářová, Ph.D.

University of Veterinary and Pharmaceutical Sciences

Department of Public Veterinary Medicine and Toxicology

Palackého 1 - 3, 61242 Brno, Czech Republic

Phone: +420 541562773

E-mail: voslarovae@vfu.cz

http://www.vfu.cz/acta-vet/actavet.htm 
Thurston (1977) on rainbow trout also suggested that larger fish are slightly more sensitive to nitrite. Bartlett and Neumann (1998) came to the same conclusion after studying sensitivity of brown trout alevins (Salmo trutta L.) to nitrite at different chloride concentrations. Thurston et al. (1978) reported no difference in the sensitivity of cutthroat trout (Oncorhynchus clarkii) weighing 1 and $3 \mathrm{~g}$. Palachek and Tomasso (1984) followed the relationship between size and nitrite toxicity in warmwater fish, and concluded that fathead minnows (Pimephales promelas) weighing between 0.3 and $0.8 \mathrm{~g}$ were more tolerant of nitrite than fish weighing from 0.9 to $3.3 \mathrm{~g}$. The $96 \mathrm{hLC} 50$ for the smaller fish was about 50\% higher than that of the larger fish. Atwood et al. (2001) found in a lethal experiment conducted on Nile tilapia (Oreochromis niloticus), that tolerance to nitrite was significantly affected by fish size. The $96 \mathrm{hLC} 50$ for smaller fish (average weight $4.4 \pm 1.50$ g) was $266.17 \mathrm{mg} \cdot \mathrm{l}^{-1} \mathrm{NO}_{2}{ }^{-}$and larger fish $(90.7 \pm 16.43 \mathrm{~g})$ demonstrated $96 \mathrm{hLC} 50$ of 26.29 $\mathrm{mg} \cdot \mathrm{l}^{-1} \mathrm{NO}_{2}^{-}$.

No definite explanation of better tolerance of young fish to higher ambient nitrite concentrations has been put forward to date. There may be a variation in the activity of the methaemoglobin reductase system between young and adult individuals (Kiese 1974). Another explanation may be found in the differing respiratory physiology of larvae and adults (Balon 1975; Rombough and Moroz 1990; Siwicki 1994; Bartlett and Neumann 1998). Specific features of development of the gill system during the ontogenesis of zebrafish (Danio rerio) were described by Shadrin and Ozerny uk (2002). Furthermore, Jonz and Nurse (2005) described the ontogenesis of $\mathrm{O}_{2}{ }^{-}$chemoreceptive properties of neuroepithelial cells of the zebrafish gill filaments, and the formation of functional $\mathrm{O}_{2}^{-}$sensing pathways in developing $D$. rerio.

The most important external ambient factor to influence nitrite toxicity for fish is chlorides. A positive effect of increased chloride concentration in water was observed in various fish species (Crawford and Allen 1977; Russo and Thurston 1977; McConnell 1985; Mazik etal. 1991; Atwood et al. 2001; Jensen 2003; Lin and Chen 2003; Dvořák 2004; Svobodová et al. 2005a,b). In D. rerio aged $2-3$ months Pištěková et al. (2005) determined a logarithmical relationship between $96 \mathrm{hLC} 50 \mathrm{NO}_{2}^{-}$ and chloride concentrations in diluting water. All studies investigating the effects of nitrites on various fish species, their different developmental stages, etc., must therefore always take into account water chloride concentrations.

The aim of the present study was to compare the acute nitrite toxicity level for Danio rerio at age of 20 - 25 days and $2-3$ months at various chloride concentrations. The toxicity tests were performed on aquarium fish $D$. rerio because this species is at present most frequently used worldwide for toxicity tests (OECD and ISO methodological guidelines).

\section{Materials and Methods}

Tests of acute toxicity were performed on aquarium fish Danio rerio (Cyprinus rerio (Hamilton 1822)) according to ,Catalog of Fishes 2004“) aged $20-25$ days (larval stage) and $2-3$ months (juvenile stage). The procedure complied with OECD No. 203 Acute Toxicity Test on Fish - Semistatic Method guidelines. A total of 6 series of experiments with different $\mathrm{NO}_{2}{ }^{-}$and $\mathrm{Cl}^{-}$concentrations in the diluting water were made:

Fish aged 20 - 25 days acclimatized for $96 \mathrm{~h}$ with $19 \mathrm{mg} \cdot \mathrm{l}^{-1} \mathrm{Cl}^{-}$

1. $\mathrm{Cl}^{-}$test concentration $19 \mathrm{mg} \cdot \mathrm{l}^{-1}$

2. $\mathrm{Cl}^{-}$test concentration $50 \mathrm{mg} \cdot \mathrm{l}^{-1}$

3. $\mathrm{Cl}^{-}$test concentration $100 \mathrm{mg} \cdot \mathrm{l}^{-1}$

Fish aged $2-3$ months acclimatized for $96 \mathrm{~h}$ with $19 \mathrm{mg} \cdot \mathrm{l}^{-1} \mathrm{Cl}^{-}$

4. $\mathrm{Cl}^{-}$test concentration $19 \mathrm{mg} \cdot \mathrm{l}^{-1}$

5. $\mathrm{Cl}^{-}$test concentration $50 \mathrm{mg} \cdot \mathrm{l}^{-1}$

6. $\mathrm{Cl}^{-}$test concentration $100 \mathrm{mg} \cdot \mathrm{l}^{-1}$

In each test series, 5 tests of acute toxicity were made, with 10 fish used for each concentration and for the control group.

Basic physical and chemical indices of diluting water used in the acute toxicity tests were following: $\mathrm{ANC}_{4.5}$ 
(acid neutralisation capacity) $3.56-3.75 \mathrm{mmol} \cdot \mathrm{l}^{-1}$; $\mathrm{COD}_{\mathrm{Mn}}$ (chemical oxygen demand) $1.34-1.91 \mathrm{mg} \cdot \mathrm{l}^{-1}$; total ammonia below detection limit; $\mathrm{NO}_{3}{ }^{-} 24.35-31.40 \mathrm{mg} \cdot \mathrm{l}^{-1} ; \mathrm{NO}_{2}{ }^{-}$below detection limit; $\mathrm{Cl}^{-} 18.9-19.1 \mathrm{mg} \cdot \mathrm{l}^{-1} ; \mathrm{sum}$ of $\mathrm{Ca} \pm \mathrm{Mg} 14 \mathrm{mg} \cdot \mathrm{l}^{-1}$. Water temperatures in the tests ranged $23 \pm 1{ }^{\circ} \mathrm{C}$, oxygen saturation of water was above $60 \%$ (ranging from 76 to 93\%), $\mathrm{pH}$ ranged from 8.10 to 8.67. Nitrites and chlorides were metered in the form of $\mathrm{NaNO}_{2}$ and $\mathrm{NaCl}$, respectively.

During the tests, the condition of fish was checked at 24-hour intervals and the number of dead fish was recorded for different concentrations. No fish from the control group died during any of the tests. The results obtained (numbers of fish dying at individual test concentrations) were processed by the probit analysis (EKO-TOX 5.1 software) to determine the $96 \mathrm{hLC} 0 \mathrm{NO}_{2}^{-}$value. For statistical processing of results (basic statistics, correlations

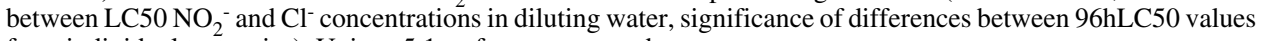
from individual test series), Unistat 5.1. software was used.

\section{Results}

The acute $\mathrm{NO}_{2}^{-}$toxicity to $D$. rerio aged $20-25$ days as expressed by the $96 \mathrm{hLC} 50$ was $386.00 \pm 29.75 \mathrm{mg} \cdot \mathrm{l}^{-1}$. The $96 \mathrm{hLC} 50 \mathrm{NO}_{2}{ }^{-}$for $D$. rerio aged $2-3$ months was $242.41 \pm 13.67$ $\mathrm{mg} \cdot \mathrm{l}^{-1}$. These results were obtained with chloride concentration naturally occurring in the diluting water used, i.e. $19 \mathrm{mg} \cdot \mathrm{l}^{-1}$. We observed an increase in $96 \mathrm{hLC} 50 \mathrm{NO}_{2}^{-}$in D. rerio of both developmental stages following an increase in $\mathrm{Cl}$ - concentration in diluting water. A comparison between the $96 \mathrm{hLC} 50 \mathrm{NO}_{2}{ }^{-}$for $D$. rerio aged $20-25$ days and $2-3$ months at different chloride concentrations in diluting water $\left(19 ; 50 ; 100 \mathrm{mg} \cdot \mathrm{l}^{-1}\right)$ showed a highly significant increase $(p<0.01)$ in the 96hLC50 $\mathrm{NO}_{2}^{-}$for younger fish at all chloride concentrations. The comparison of $96 \mathrm{hLC} 50 \mathrm{NO}_{2}^{-}$for $D$. rerio at age of $20-25$ days and $2-3$ months obtained in acute toxicity tests with different $\mathrm{Cl}^{-}$concentrations in diluting water is given in Fig. 1. Significant differences in $96 \mathrm{hLC} 50 \mathrm{NO}_{2}^{-}$values for $D$. rerio aged $20-25$ days were found between tests with chloride concentrations of 19 and $100 \mathrm{mg} \cdot \mathrm{l}^{-1}$ $(p<0.05)$ and 50 and $100 \mathrm{mg} \cdot \mathrm{l}^{-1}(p<0.05)$. The difference in $96 \mathrm{hLC} 50 \mathrm{NO}_{2}{ }^{-}$values between tests with chloride concentrations of 19 and $50 \mathrm{mg} \cdot \mathrm{l}^{-1}$ was not statistically significant. In $D$. rerio aged $2-3$ months, on the other hand, significantly reduced nitrite toxicity $(p<0.05)$ was observed at the concentration of $50 \mathrm{mg} \cdot \mathrm{l}^{-1} \mathrm{Cl}^{-}$in diluting water.

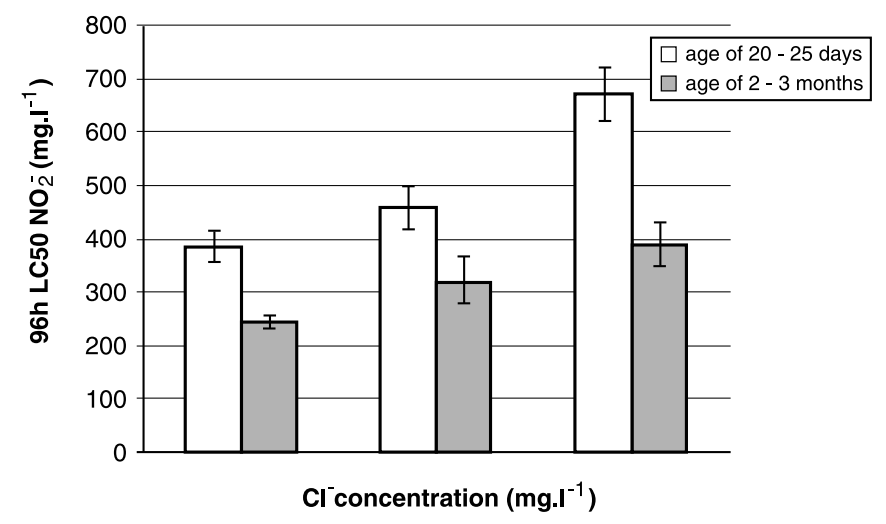

Fig. 1. Effects of higher chloride concentrations in diluting water to 96hLC50 $\mathrm{NO}_{2}{ }^{-}$in Danio rerio aged $20-25$ days (test series 1, 2 and 3 ) and $2-3$ months (test series 4, 5 and 6)

Statistical evaluation of 96hLC50 $\mathrm{NO}_{2}^{-}$values obtained in acute toxicity tests when diluting water with increasing chloride concentrations was used $\left(19-100 \mathrm{mg} \cdot \mathrm{l}^{-1}\right)$ demonstrated a logarithmical (D. rerio aged 2 - 3 months), and exponential (D. rerio aged 
20 - 25 days) relationship, respectively, between 96hLC50 $\mathrm{NO}_{2}^{-}$and chloride concentrations in diluting water (Fig. 2). The resulting regression equation for $D$. rerio aged $2-3$ months is $\mathrm{y}=-15.26+86.69 \operatorname{Ln}(\mathrm{x})(\mathrm{I}=0.856)$ and for $D$. rerio aged $20-25$ days is $\mathrm{y}=$ $332.69 \mathrm{e}^{0.0068 \mathrm{x}}(\mathrm{I}=0.849)$, where $x$ is chloride concentrations in diluting water $\left(\mathrm{in} \mathrm{mg} \cdot \mathrm{l}^{-1} \mathrm{Cl}\right)$ and $y$ is the value of 96hLC50 (in $\mathrm{mg} \cdot \mathrm{l}^{-1} \mathrm{NO}_{2}^{-}$).

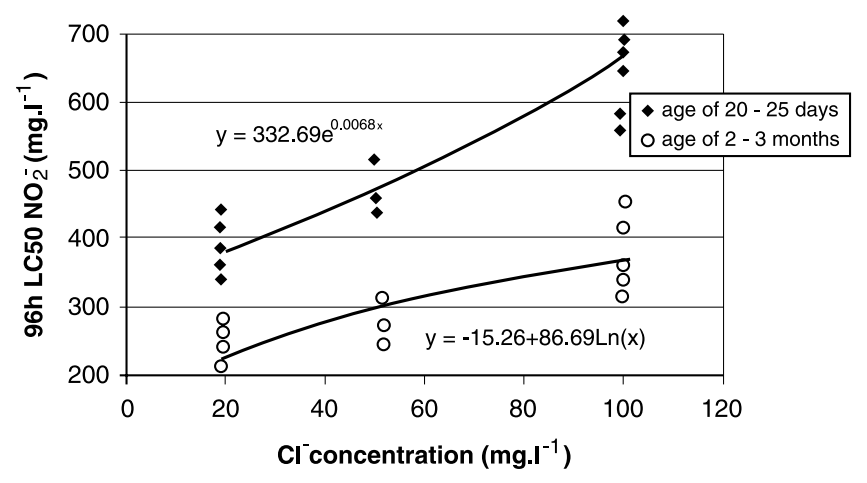

Fig. 2. Relationship between chloride concentrations in diluting water and $96 \mathrm{hLC} 50 \mathrm{NO}_{2}^{-}$values in Danio rerio aged 20 - 25 days (test series 1,2 and 3) and Danio rerio aged $2-3$ months (test series 4, 5 and 6 )

\section{Discussion}

Tests of $\mathrm{NO}_{2}^{-}$acute toxicity performed at different chloride concentrations in diluting water confirmed in both developmental stages of $D$. rerio the positive effect of increased chloride concentrations in the aquatic environment on the reduction of nitrite toxicity, which had previously been also described in various other fish species (Crawford and Allen 1977; Russo and Thurston 1977; McConnell 1985; Mazik et al. 1991; Atwood et al. 2001; Jensen 2003; Lin and Chen 2003; Dvořák 2004; Svobodová et al. 2005a,b; Pištěková et al. 2005). It can be concluded from the computed regression equation of relationship between $96 \mathrm{hLC} 50 \mathrm{NO}_{2}{ }^{-}$and chloride concentrations in diluting water that 1 $\mathrm{mg} \cdot \mathrm{l}^{-1}$ increase in chloride concentration in diluting water results in the case of $D$. rerio aged

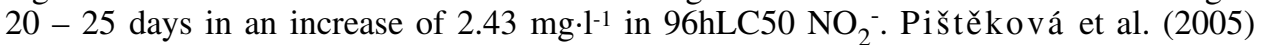
reported an increase of $8.27 \mathrm{mg} \cdot \mathrm{l}^{-1}$ in $96 \mathrm{hLC}^{-} \mathrm{NO}_{2}{ }^{-}$in $D$. rerio aged $2-3$ months. It follows from the above that positive effects of higher chloride concentrations were greater in older fish than in young fish. A comparison between $96 \mathrm{hLC} 50 \mathrm{NO}_{2}^{-}$determined for $D$. rerio from two different developmental stages at different chloride concentrations in diluting water (19; $\left.50 ; 100 \mathrm{mg} \cdot \mathrm{l}^{-1}\right)$ showed a consistent, statistically highly significant increase $(p<0.01)$ in $96 \mathrm{hLC} 50 \mathrm{NO}_{2}^{-}$values for the younger fish. Younger developmental stages of D. rerio are therefore demonstrably more tolerant to higher ambient nitrite concentrations.

Increased tolerance of fish of lower developmental stages to higher ambient nitrite concentrations has been demonstrated by tests for Oncorhynchus kisutch (Perrone and Meade 1977), Salmo gairdneri (Smith and Williams 1974; Rus so et al. 1974; Russo and Thurston 1977), Salmo trutta L. (Bartlett and Neumann 1998), Pimephales promelas (Palachek and Tomasso 1984) and Oreochromis niloticus (Atwood et al. 2001). On the other hand, Thurst on et al. (1978) reported no difference in the sensitivity of cutthroat trout (Oncorhynchus clarkii) of two weight categories (1 and $3 \mathrm{~g}$ ). This, however, could be explained by the very small size range of the fish. Palachek and 
Tomasso (1984) found that 96hLC50 $\mathrm{NO}_{2}^{-}$values in fathead minnows (Pimephales promelas) weighing between 0.3 and $0.8 \mathrm{~g}$ were about $50 \%$ higher than those of fish weighing from 0.9 to $3.3 \mathrm{~g}$. An even greater difference in tolerance to nitrites in relation to age was found by Atwood et al. (2001) in Nile tilapia (Oreochromis niloticus). The 96hLC50 for smaller fish (average weight $4.4 \pm 1.50 \mathrm{~g}$ ) was $266.17 \mathrm{mg} \cdot \mathrm{l}^{-1} \mathrm{NO}_{2}{ }^{-}$and larger fish $(90.7 \pm 16.43 \mathrm{~g})$ demonstrated a $96 \mathrm{hLC} 50 \mathrm{of} 26.29 \mathrm{mg} \cdot \mathrm{l}^{-1} \mathrm{NO}_{2}{ }^{-}$. That means that the difference between the $96 \mathrm{hLC} 50 \mathrm{NO}_{2}^{-}$in Nile tilapia from the two weight categories was approximately tenfold. In our experiment, the $96 \mathrm{hLC} 50 \mathrm{NO}_{2}{ }^{-}$values for $D$. rerio aged $20-$ 25 days and those aged $2-3$ months were $386.00 \pm 29.75 \mathrm{mg} \cdot 1^{-1}$ and $242.41 \pm 13.67 \mathrm{mg} \cdot 1^{-1}$, respectively, at the chloride concentration naturally occurring in the diluting water used (i.e. $19 \mathrm{mg} \cdot \mathrm{l}^{-1}$ ). It means that nitrite toxicity for $D$. rerio was almost $40 \%$ higher for the older fish than for the younger fish. The difference in 96hLC50 $\mathrm{NO}_{2}^{-}$between older and younger $D$. rerio at higher chloride concentrations in the diluting water remained approximately at the same level. At the $50 \mathrm{mg} \cdot l^{-1} \mathrm{Cl}^{-}$concentration in diluting water, the difference in the 96hLC50 NO $\mathrm{NO}_{2}^{-}$between older and younger $D$. rerio was $31 \%$, while at $100 \mathrm{mg} \cdot \mathrm{l}^{-1} \mathrm{Cl}^{-}$ concentration in the diluting water, the $96 \mathrm{hLC}^{2} 0 \mathrm{NO}_{2}^{-}$for younger fish was $43 \%$ higher.

Various explanations of increased tolerance of smaller fish to nitrite have been put forward. Kiese (1974) attributed it to differences in the activity of the methaemoglobin reductase system between young and adult individuals. Si wi cki et al. (1994) explain higher tolerance of young trout to nitrites by a higher oxygen-binding capacity of haemoglobin in young fish compared with older ones. Balon (1975) looked for an explanation in the differing respiratory physiology of larvae and adults. Since scales first start to form near the end of the alevin phase of development, cutaneous oxygen uptake is higher for fry than for adults. The surface area to total mass ratio is considerably higher for younger fish, allowing a higher rate of oxygen diffusion (Rombough and Moroz 1990). Due to these factors, oxygen taken up through the skin is able to permeate to the internal tissues far better in alevin than in older fish. As nitrite is a blood poison, fry may be able to survive longer under reduced oxygen-carrying capacity of the blood than would an adult, which depends on the oxygen delivered by the blood stream for survival (Bartlett and Neumann 1998). In $D$. rerio, this theory is also supported by conclusions arrived at by Shadrin and Ozernyuk (2002) in their study of differences in the gill system of individual developmental stages of D. rerio. The authors pointed out that differentiation of gills in zebrafish was accompanied by a manifold increase in the oxygen consumption rate. At different developmental stages, the incremental rates of oxygen consumption and increase in the body mass of the zebrafish larvae and fry differed significantly. Also Jonz and Nurse (2005) found significant differences in oxygen sensing pathways in the gills of $D$. rerio during development.

The nitrite uptake in freshwater fish is active through chloride cells of the gill apparatus (Maetz 1971; Williams and Eddy 1986; Jensen 2003). In the larval stages of fish, gills are not fully developed and thus the exchange of gases $\left(\mathrm{O}_{2}, \mathrm{CO}_{2}\right)$ through the skin predominates (Bartlett and Neumann 1998). We therefore assume that the nitrite uptake in larvae and fry is lesser than that in juvenile fish, which makes them more tolerant to higher nitrite concentrations in the aquatic environment than fish with fully developed gill apparatus.

\section{Toxicita dusitanů pro danio pruhované (Danio rerio): vliv věku ryb a koncentrace chloridů}

Cílem předložené práce bylo porovnat akutní toxicitu $\mathrm{NO}_{2}{ }^{-}$pro Danio rerio ve věku 20 25 dní (larvální stadium) a $2-3$ měsíce (juvenilní stadium) př̌i různé koncentraci $\mathrm{Cl}^{-} \mathrm{v}$ ředicí vodě. Testy byly provedeny semistatickou metodou podle OECD 203. Byla stanovena hodnota $96 \mathrm{hLC} 50 \mathrm{NO}_{2}^{-} 386,00 \pm 29,75 \mathrm{mg} \cdot \mathrm{l}^{-1}$ (pro D. rerio ve věku $20-25$ dní), resp. 
$242,41 \pm 13,67 \mathrm{mg} \cdot \mathrm{l}^{-1}$ (pro $D$. rerio ve věku $2-3$ měsíce) při koncentraci $19 \mathrm{mg} \cdot \mathrm{l}^{-1} \mathrm{Cl}^{-} \mathrm{v}$ ředicí vodě. U obou vývojových stádií $D$. rerio byl zjištěn nárůst hodnoty $96 \mathrm{hLC} 50 \mathrm{NO}_{2}^{-}$po zvýšení koncentrace $\mathrm{Cl}^{-}$v ředicí vodě. Při porovnání hodnot $96 \mathrm{hLC} 50 \mathrm{NO}_{2}^{-}$stanovených u ryb $D$. rerio ve věku $20-25$ dní a $2-3$ měsíce při různé koncentraci chloridů v ředicí vodě $\left(19 ; 50 ; 100 \mathrm{mg} \cdot \mathrm{l}^{-1}\right)$ byla zjištěna ve všech případech významně vyšší $(p<0,01)$ hodnota $96 h L C 50 \mathrm{NO}_{2}^{-}$u mladších ryb. U ryb $D$. rerio ve věku $20-25$ dní byla zjištěna exponenciální závislost mezi hodnotou $96 \mathrm{hLC} 50 \mathrm{NO}_{2}{ }^{-}$a koncentrací chloridů v ředicí vodě ( $\mathrm{I}=0,849)$, zatímco u ryb $D$. rerio ve věku $2-3$ měsíce byla zjištěna závislost logaritmická $(\mathrm{I}=0,856)$.

\section{Acknowledgements}

The research was supported by the Ministry of Education, Youth and Sports (MSM project No. 6215712402).

\section{References}

ADAMSSON M, DAVE G, FOSBERG L, GUTERSTAM B 1998: Toxicity identification evaluation of ammonia, nitrite and heavy metals at the Stensund wastewater aquaculture plant, Sweden. Water Sci Technol 38: 151-157

ATWOOD HL, FONTENOT QC, TOMASSO JR, ISELY JJ 2001: Toxicity of nitrite to Nile tilapia: effect of fish size and environmental chloride. North Am J Aquaculture 63: 49-51

BALONEK 1975: Terminology of intervals in fish development. J Fish Res Board Canada 32: 1663-1670

BARTLETT F, NEUMANN D 1998: Sensitivity of brown trout alevins (Salmo trutta L.) to nitrite at different chloride concentrations. Bull Environ Contam Toxicol 60: 340-346

CRAWFORD RE, ALLEN GH 1977: Seawater inhibition of nitrite toxicity to chinook salmon. Trans Am Fish Soc 106: $105-109$

DVOŘÁK P 2004: Selected specificity of aquarium fish disease. Bulletin VÚRH Vodňany 40: 101-108

ETSCHEIDT J 2003: Nitrogen metabolites in ornamental and pond fishkeeping. Origin, elimination and veterinary relevance. Tierarztl Prax Ausgabe Kleintiere Heimtiere 31: 244-249

JENSEN FB 2003: Nitrite disrupts multiple physiological functions aquatic animals. Comp Biochem Physiol AMol Integr Physiol 135: 9-24

JONZ MG, NURSE CA 2005: Development of oxygen sensing in the gills of zebrafish. J Exp Biol 208: 1537-1549

KIESE M 1974: Methemoglobinemia: a comprehensive treatise. CRC Press, Cleveland, $260 \mathrm{p}$.

LEWIS WM, MORRIS DP 1986: Toxicity of nitrite to fish - a review. Trans Am Fish Soc 115: 183-195

LIN YC, CHEN JC 2003: Acute toxicity of nitrite on Litopenaeus vannamei (Boone) juveniles at different salinity levels. Aquaculture 224: 193-201

MAETZ J 1971: Fish gills: mechanism of salt transfer in fresh water and sea water. Philosophical Transactions of the Royal Society of London Series B Biological Sciences 262: 209-249

MAZIK PM, HINMAN ML, WINKELMANN DA, KLAINE SJ, SIMCO BA, PARKER NC 1991: Influence of nitrite and chloride concentrations on survival and hematological profiles of striped bass. Trans Am Fish Soc 120: $247-254$

MCCONNELL R 1985: Toxicity of nitrite to the fathead minnow. Colorado Department of Health File Report, Denver.

PALACHEK RM, TOMASSO JR 1984: Nitrite toxicity to fathead minnows - effect of fish weight. Bull Environ Contam Toxicol 32: 238-242

PERRONE SJ, MEADE TL 1977: Protective effect of chloride on nitrite toxicity to coho salmon (Oncorhynchus kisutch). J Fish Res Board Canada 34: 486-492

PIŠTĚKOVÁ V, VOSLÁŘOVÁ E, SVOBODOVÁ Z 2005: Nitrite toxicity to Danio rerio: effects of chloride concentrations during acclimatization and in toxicity tests. Acta Vet Brno 74: 435-440

PITTER P 1999: Hydrochemie. VŠCHT, Praha, 568 p.

ROMBOUGH PJ, MOROZ BM 1990: The scaling and potential importance of cutaneous and branchial surfaces in young chinook salmon (Oncorhynchus tshawytscha). J Exp Biol 154: 1-12

RUSSO RC, SMITH CE, THURSTON RV 1974: Acute toxicity of nitrite to rainbow trout (Salmo gairdneri). J Fish Res Board Canada 31: 1653-1655

RUSSO RC, THURSTON RV 1977: The acute toxicity of nitrite to fishes. In: TUBB RA (Ed.): Recent Advances in Fish Toxicity. US Environmental Protection Agency, Corvallis, pp. 118-131

SHADRIN AM, OZERNYUK ND 2002: Development of the gill system in early ontogenesis of the zebrafish and ninespine stickleback. Russ J Dev Biol 33: 91-96

SIWICKI AK, ANTYCHOWICZ J, WALUGA J 1994: Choroby ryb hodowlanych. IRS, Olsztyn, 376 p.

SMITH CE, WILLIAMS WG 1974: Experimental nitrite toxicity in rainbow trout and chinook salmon. Trans Am Fish Soc 103: 89-90

SVOBODOVÁ Z, MÁCHOVÁ J, POLESZCZUK G, HŮDA J, HAMÁČKOVÁ J, KROUPOVÁ H 2005a: Nitrite poisoning of fish in aquaculture facilities with water - recirculating systems. Acta Vet Brno 74: 129-137 
SVOBODOVÁ Z, MÁCHOVÁ J, DRASTICHOVÁ J, GROCH L, LUSKOVÁ H, POLESZCZUK G, VELIŠEK J, KROUPOVÁ H 2005b: Haematological and biochemical profile of carp blood following nitrite exposure at different concentrations of chloride. Aquacult Res 36: 1177-1184

THURSTON RV, RUSSO RC, SMITH CE 1978: Acute toxicity of ammonia and nitrite to cutthroat trout fry. Trans Am Fish Soc 107: 361-368

WILLIAMS EM, EDDY FB 1986: Chloride uptake in fresh-water teleosts and its relationship to nitrite uptake and toxicity. J Comp Physiol B-Biochem Syst Environ Physiol 156: 867-872 